\title{
Thinking about and working with archives and records: a personal reflection on theory and practice
}

Introduction

The author began work in 1975. A senior colleague gave him two memorable pieces of advice during his first week in the archives profession. Firstly, he was told never to waste time on women's papers. Secondly, he was urged to make sure that anything he earmarked for disposal was actually destroyed and that no evidence of the matter was kept, lest historians should make a fuss about it later. Clearly, conventional thinking about archives and records has moved on significantly over the last forty years. During that period the author has written or co-authored about 25 publications, which deal with a range of inter-related issues that bear on record keeping; such as accountability, appraisal, orality ${ }^{i}$, the development of systems over time, transparency and associated Freedom of Information legislation and what the future might hold. Here, as a result of reflection on the development of his own thinking, his publications and the experiences that have shaped him, he sets out the position that for post-modernist approaches to archive and records theory to have a beneficial effect it is profoundly helpful to supplement them with the concepts of hermeneutics and fiduciarity and to use these concepts with a degree of granularity sufficient to provide a genuine foundation of evidence.

The author's earliest notions of archival theory were formed whilst working for the Scottish Record Office and studying at University College London. The prevailing influence was that of Sir Hilary Jenkinson and the British public records tradition for which he stood. Visiting fellowships in the USA, at Stanford in 1984 and Michigan in 1997, had a significant impact on the development of the author's thinking. The Bentley Library research programme (led by Francis Blouin) served particularly to introduce him to the vibrant American historical manuscripts tradition at a time when it was undergoing a transformation, moving away from a focus on the great and the good towards a concern to document society in a much wider and more inclusive fashion. Living and working in African countries (Zambia, 1977-79, Tanzania, 1999-2000 and Malawi in 2009 and 2011) has had a major impact also. At an early stage the author became aware of the doleful impact of one-party states on historiography. Time spent as a visiting fellow at Balliol College, Oxford, may be regarded as an extension of these African trips, at least in the sense that it enabled the author to look at the personal papers of colonial civil servants and to realise how far removed their experiences were from the prevailing stereotype of the colonial state as a monolithic regime.

Over a prolonged period, the author has engaged with ideas that can be, and are, labelled postmodernist in relation to archival and records theory. However, whilst the author engages with postmodernist discourse on records and archives, he does not regard the analytical framework provided by it as wholly satisfactory. Nor does he regard it as being as ground-breaking as some commentators imagine. Many of the points made by post-modernist commentators can be found in earlier works, albeit framed differently: Galbraith and Heussler come to mind in this context.i

\section{Post-modernism}

Four writers are particularly significant in informing the author's approach to, and understanding of, post-modernism. These are Derrida, Foucault, Fanon and Sartre. Post-modernism is a convenient portmanteau term by which to refer to a range of evolving and dynamic epistemological approaches: considering these writers helps to tease out significant strands. 
Derrida is the post-modernist most frequently cited by writers on archives. Yet his own account makes it clear he was surprised by this and did not intend to influence thinking about archival repositories or services. His writings, and the interpretations placed on them, receive attention in the next sub-section.

In the current context, Foucault's work on the history of mental illness is of particular importance because in it he asserts the validity of using imagination and fictional literature instead of relying on archives for evidence. Arguably, this has had the effect of making it academically acceptable to 'make up history'. It is significant that Foucault's doctorate was rejected when first submitted precisely because of the paucity of evidence for his assertions. The impact of Foucault's arguments in archival discourse receives more consideration below. The author is inclined to adopt a materialist line of analysis when seeking to comprehend the wider impact of Foucault's writings. In essence, Foucault's argument that academic outputs can be produced without resort to costly and time-consuming archival research resonates readily in an era during which higher education has expanded much more rapidly than the funds available to support research in the humanities.

Fanon was an advocate of violent resistance to colonialism who, paradoxically, served the French state for almost 20 years. Inter alia, he is remembered for the argument that colonial rule inflicted lasting psychological damage on black people which might be rectified by killing white people - an argument that was endorsed by Sartre. Although direct citation of Fanon is not common in African literature about archives, he has had a lasting influence on postcolonial theory which in turn has influenced African discourse about archives and records.

Sartre is significant in this context because his Roads to Freedom trilogy points towards a key unifying experience that lies behind the phenomenon of post-modernism: the collapse of France in 1940. For all four of the writers named here, defeat was as much a moral as a military disaster. The death of Mathieu, the main character in the Roads to Freedom trilogy, who opts to fight the invading German army when those around him are deserting represents what Sartre and others wished they had done. In referring to Sartre, the author is conscious that he is following Foucault in using fictional sources.

Derrida, Foucault, Fanon and Sartre were all, in different ways, marginal or marginalised people. Derrida was a Jew whose response to being excluded from school by the Vichy authorities was to exclude himself from the alternative school set up by Jewish people; Foucault was a sadomasochist whose interest in restraint and punishment was as much recreational as academic; Fanon raged against colonialism but alienated himself from his roots in the West Indies by opting to serve in the French Army rather than go home and provide medical services there; and, Sartre theorised and fantasised about resisting fascism but played no active part in resistance to the German occupation of France. The position of South African commentators on archives resonates with the marginality of the leading post-modernist thinkers, as is outlined below. The author's work, in contrast, focusses on the mainstream of public service record keeping. This, however, does not imply a lack of concern with disadvantaged people and communities. Good governance and anti-corruption initiatives, which exist to ensure that public sector resources are properly utilised, are core concerns of a number of his publications.iii Given that about one quarter of Africa's GDP is lost through corrupt practices, the search for good governance strategies is of direct benefit to some of the poorest people in the world. ${ }^{\text {iv }}$

\section{Post-modernism and archival discourse}

The bulk of the literature on post-modern critiques of archives has its origins in France or the USA with recently some interesting contributions from South Africa. Strikingly, the archival discourse of Sub-Saharan Africa to the north of South Africa is quite distinct from the South African equivalent. 
There has also been a spirited contribution from the former Director of The National Archives [TNA] in the UK, Sarah Tyacke: this is essentially in defence of archives.

Tyacke makes several significant points

- Where "consensus on what the state and society should be doing does not exist or ... the very existence of the state becomes an issue ... then the archives becomes a battleground."v

- What historians look to archives for is "insight into the past, which is beyond fiction or selfreferential textual interpretation." ${ }^{\mathrm{vi}}$

- That "archives and archiving are part of a continuing dialogue between the past and the present for the future ..."vii

The last point amounts to an acceptance that there is no final and absolute historical truth. She concedes also that record creation is not necessarily benign.

French critiques come from outwith archive profession. They are highly theoretical and characterised by what van Zyl calls "unashamed opacity": they are often more like riddles than expositions. viii At the heart of this opacity lies a great reluctance to define terms. 'Archive' is sometimes used to mean record repository, sometimes the whole canon of western civilisation (as viewed from a French perspective) and sometimes in a way that confuses personal papers with institutional records.

The last point is particularly relevant to Derrida's 'Archive fever'. ${ }^{i x}$ This had its origins in a paper presented to a conference on psychoanalysis and psychiatry in 1994. A number of art historians were present but no archivists. Derrida himself later explained that the paper was primarily written in an attempt to ingratiate himself with Yosef Yerushalmi (an historian of Judaism and psychoanalysis). ${ }^{x}$ The focus of 'Archive fever' is the personal papers of Sigmund Freud.

Derrida has a tendency to make broad sweeping generalisations founded on a very narrow empirical basis. Both Derrida and Yerushalmi regard an inscription written by Sigmund Freud's father in a presentation bible as a 'canonical text', a foundation stone on which the Freud archive is built. Derrida makes much of the domiciliation of archives - that official records in ancient Greece were stored in the homes of senior magistrates. This is no longer true of most official records today. Indeed it is inherent in Weber's characterisation of rational bureaucracies that there is a clear distinction between the office and the official's home. Nor do official records correspond to the usage of the term archives in most of Derrida's work: sometimes publications appear to be at the heart of his concerns, at other times private correspondence. Ultimately there is a spiritual mysticism about Derrida's work which is epitomised by his statement that 'archive fever verges on radical evil' . ${ }^{\text {i }}$ In Derrida's work there is an opposition of Devil to God, of Jew to Aryan and of destruction to preservation that he relates to archives. Such heroic struggles seem far removed from the experience of most British record keeping professionals.

The history of psychiatry is a major theme for critics, especially French critics, of archives. Foucault's writings on the supposed 'grand incarceration' purport to represent a history of the abuse of

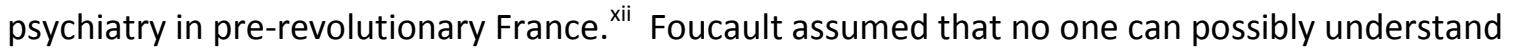
what was really going on in the mind of another based on the records of asylums. So his writings are not based primarily on archival research but on imagination and passages culled from literature.

As Foucault has, apparently, rendered acceptable the use of fiction as evidence, it is worth quoting here a passage from Byatt's novel 'Possession': the topic of conversation is academic research and a 
choice is posited between laborious archival research and a less onerous approach to scholarship. The characters Roland and Fergus are competitors in academic enterprise and Fergus is trying to obtain information from Val, Roland's partner, without arousing any suspicion that he - Fergus - is engaged in stealing the product of a colleague's intellectual labours:

Val "Honestly I've lost interest in all his footnotes and things and all those dead letters from dead people ... and all that stuff. Who wants to spend their life in the British Museum basement? It smells as bad as Mrs Jarvis's flat up there, full of cat piss. Who wants to spend their life reading old menus in cat piss?"

Fergus "Nobody. They want to spend their lives in lovely hotels at international conferences." "xiii

It is not facetious to suggest that one reason why Foucault's theories have proved influential is hinted at in this passage.

Another strand in Foucault's thinking is a rejection of the self-consciously nation-building agenda of the French Archives National. As civil servants, the archivists of France serve a highly centralised government with an avowedly secularist nature and a related tendency to be hostile to or simply forgetful of minorities, whether ethnic, religious or regional. Foucault's sexual orientation made it natural that he should adopt an 'outsider' perspective.

The work of Parry-Jones stands as a contradiction of Foucault's assertion that studies carried out in the archives of asylums and of related supervisory bodies are inherently meaningless. Parry-Jones's 'Trade in lunacy' demonstrates that if the scholar understands psychiatry then it is possible to derive real insights that are beyond fiction or self-referential textual interpretation. ${ }^{\text {xiv }}$ Parry-Jones was a psychiatrist turned historian and his insights as a practitioner contrast markedly with Foucault's position as an outsider.

Psychiatry is also the field of Stanley Raffel, an American contributor to this strand of discourse. Interestingly Raffel was interested in current record keeping rather than with the past. He studied clinical records management in the largest psychiatric hospital in New York State. ${ }^{\mathrm{xV}}$ One of his critiques concerns the practise of psychiatrists writing case summaries (in respect of patients being discharged) that serve a range of purposes. They contain information needed for the hospital's administrative purposes. They are added to the case notes for reference (particularly in case the patient is re-admitted). They are sent to the patient's doctor in the community. This practice Raffel interprets as a sinister device, designed by the hospital administration to secure social control. Alternatively, it possible to view the case summaries as an economical and efficient method for distributing information where and when it is needed. ${ }^{\text {xvi }}$

Before leaving the field of (anti-) psychiatry, it is worth mentioning R. D. Laing. The point here is that Laing's publications (in Derridian terms part of the archive) assert that patients treated by him in the 'rumpus room' recovered and were discharged. ${ }^{\text {xvii }}$ The hospital records (archives in a conventional sense) show, however, that this is demonstrably false. xviii In fact, one of the patients that Laing claimed to have successfully cured in the 1950s never left Gartnavel Royal Hospital and died there recently. ${ }^{\mathrm{xix}}$

North American contributions followed the French, chronologically. Many American and Canadian writers refer to the French literature. However, some do not seem to be fully aware of the much broader meanings that are sometimes attached by the French to the term 'Archive'. A significant factor, often overlooked, is that the North American contributors to the literature are not evenly distributed across the record keeping professions. The National Archives and Records 
Administration [NARA] has made little impact on discourse about archive and records theory in recent decades.

The major contributors to American literature on societal memory have tended to come from two kinds of institutions - historical societies and research universities. What these have in common is that they collect. Unlike NARA or TNA, they do not exist to deal with whatever records the functioning of government produces. Instead they accumulate a mass of records of business companies, labour unions, interest groups etc and the personal papers of activists, campaigners, retired generals, ex-congressmen, those who style themselves 'community activists', writers, intellectuals, and so forth. Whilst the members of staff in these institutions usually possess archival skills, they are distinguished from many colleagues by the need to consciously construct a 'universe to be documented'. Developments in historical and cultural scholarship have left them feeling particularly vulnerable to accusations of elitism.

Francis Blouin's article 'Archivists, mediation and constructs of social memory' may be taken as representative of much American writing and incorporates references to a wide range of other authors' contributions to this discourse. The essay makes a number of interesting points. For Blouin, challenges arise from "many disciplines who find in the archives not a neutral party, but rather forces complicit with dominant cultural and political aims" and who think that "the absences in the archives ... may be purposeful in selectivity ..." ${ }^{\prime x x} \mathrm{He}$ argues that academics in cultural studies are questioning whether archives are appropriate for constructing a sense of social history. He puts this in a context of changing concepts of historical study - away from great people and institutions and towards "underrepresented minority groups, issues of gender, race, etc all of which are not easily studied through existing documentation"

Blouin notes Derrida's idea of 'domiciliation' and draws from it the implication that documents may lose part of their meaning by being removed from the setting they document. This is particularly apposite in relation to the Bentley Library at Michigan University that Blouin headed at the time. Blouin draws heavily on Carolyn Steedman. She states "The archive is not potentially made up of everything ..." as if this was a new discovery. ${ }^{x \mathrm{xi}}$ "For Steedman there are many pasts, only some of which are represented in the archive." ${ }^{\prime x i i i}$ This is patently true but not necessarily a cause for panic.

Blouin refers to the work of Joan Schwartz in photography. He states "For Schwartz the "process of picturing" is very much a subjective one." "xiv This begs the question - is this a new development? It is possible to conceive of circumstances where photographs are being made for a strictly limited business purpose, e.g. recording welds made during dry dock repairs to a ship. In these circumstances the element of subjectivity may be limited. Nonetheless, it must surely be the case that subjectivity has played a major role in photography from its inception.

Blouin discusses way in which the concept of the archive is being broadened to "... an abstraction of a very complex set of institutional, conceptual and political issues." ${ }^{\prime x v}$ He illustrates this with reference to an exhibition by the artist Renee Green on the "Vietnam era" which consisted of installations, sculptures and texts. Blouin states that "The installation ... was an archive ..." in the manner of Derrida. ${ }^{\text {xxvi }}$ However, it may be that in treating exhibitions and films as part of 'The Archive' Blouin, in common with many North American writers, has fallen into a trap. He has adopted a concept of archives that is much broader than anything he is called on to manage and which goes far beyond the capacity of record keeping professionals to cope with or even seriously influence.

Issues highlighted by the archives of the former USSR are also considered by Blouin. These he says were "collected and described under one set of authorities within a state system and now must be read within the context of another". ${ }^{x x v i i}$ Blouin's colleague Rosenburg argues that "the Soviet 
archival record was corrupted" ${ }^{\prime \prime x v i i i ~}$ and that its use corrupts social memory. There is a parallel here with many other official records, the use of which requires some insight into an official mindset or mindsets. The argument about corrupting social memory is surely open to question: this may be true if the records are interpreted poorly but it is not necessarily the case.

There have been distinctive and significant contributions to archival discourse from post-Apartheid South Africa. A key figure is Harris, although he is by no means the only contributor. Many of the participants in the South African debates were anti-apartheid activists from the minority white community. They believed or, at least, hoped that a new just, fair, open and democratic society would be created in the wake of Apartheid. This is an essential part of the context for their writings: they really do feel they are outsiders, part of a minority within a minority.

There have been substantial contributions to South African discourse on archives from anthropologists. These incorporate a considerable element of hostility to historical methods and historians and archivists. For instance, Laura Ann Stoler writes "... thinking about archives [is] no longer the pedestrian pre-occupation of 'spadework' historians [and] flat-footed archivists ...". Most of the anthropologists engaged in this discourse write as if they have recently 'discovered' archives: there is no apparent awareness of Lewis Gann's promotion of archives to anthropologists in Africa during the 1950s. ${ }^{\mathrm{xxx}}$

There is also an understandable concern with colonial records. In some respects this parallels Blouin's discourse on the archives of the former USSR. Interestingly, Laura Ann Stoler states

"How can students of colonialisms so quickly and confidently turn to readings 'against the grain' without a prior sense of their texture and granularity? ... If a notion of colonial ethnography starts from the premise that archival production is both a process and a powerful technology of rule, then we need not only to brush against the archive's received categories. We need to read for its regularities, for its logic of recall, for its densities and distributions, for its consistencies of misinformation, omission and mistake, along the archival grain." ${ }^{\prime x \times i}$

In other words, if you want to understand and use archives then you need first of all to understand the context in which they were created. This issue will be discussed below in the section on hermeneutics and fiduciarity.

Before moving on, it may be appropriate to offer the following summary. Firstly, much of the discussion of the role of record keeping professionals in relation to societal memory has tended to focus on experience in the realms of photography and the performing arts. Records created by the public sector have received inadequate attention. Secondly, and partly as a consequence of the first point, the concept that the purposes of records creation are significant has been distorted. The instinct to leave a trace has been given primacy because so much of the debate has focussed on the individual: this is evident in Derrida's remark "You cannot keep an archive inside yourself". xxxii Thus the need to transact business, whether public or private has been thrust to the margins of debate. Yet an understanding of why official and business records are created is usually crucial to their interpretation. This observation leads on to another cardinal point. Most North American writings about archives and postmodernism implicitly assume that records are created first and foremost to provide archives rather than as a by-product of business activity. A noteworthy exception is Victoria Lemieux, founder of the Centre for the Investigation of Financial Electronic Records at the University of British Columbia, who has, of necessity, engaged with the primary role of records and record keeping systems in the administration of current business activities. ${ }^{\text {xxxiii }}$ Thirdly, there may be helpful distinctions to be made between business-oriented purposes and creativity. 
This discussion does matter. Post-modern notions of archives are entering popular consciousness. An example can be found in the novel 'Human traces' in which a patient in an asylum is employed in re-writing the patients' records. ${ }^{\text {xxiv }}$ This is an absurd misrepresentation of the past but nonetheless will influence collective societal memory.

\section{Hermeneutics and fiduciarity}

Hermeneutics is an approach to scholarship originally pioneered by theologians who of necessity must face the challenge of interpreting sources created many years ago in foreign lands. An example may help to clarify this. The Bible states that Christ taught the parable of the mustard seed:

The kingdom of heaven is like a mustard seed that someone took and sowed in his field; it is the smallest of all seeds but when it has grown it is the greatest of shrubs and becomes a tree, so that the birds of the air come and make nests in its branches ${ }^{\times \times x v}$

There are several aspects of this parable that may cause contemporary readers difficulty in comprehending the meanings that Christ's listeners are likely to have attached to the text. Firstly, mustard was not used as a condiment in Palestine two thousand years ago. It was regarded as a weed. In other words, contemporary attitudes to mustard are radically different from those of Christ's audience. Secondly, the idea of planting one mustard seed in ground otherwise devoted to another crop would have shocked orthodox Jews because their established customs prohibited sowing more than one seed in a single field. ${ }^{x x v v i}$ Thirdly, the expectations of Christ's contemporaries in terms of the architecture associated with Kingship were shaped by the grandeur of Egypt, Babylon and Jerusalem. The idea that the kingdom of heaven resembled a bush that they knew to be untidy and straggling would also have been shocking. ${ }^{\text {xxvii }}$

Hermeneutics has been taken up in other disciplines too and the author regards it as a valuable supplement and alternative to straightforwardly postmodernist approaches. ${ }^{x x v i i i}$ The author's work on orality in relation to the written record and on the development of colonial record keeping systems (with Paul Lihoma), has benefitted from the adoption of hermeneutics, not least, because we regard this approach as requiring a high degree of granularity. ${ }^{\text {xxxix }}$ Perhaps the most striking of the results has been the finding that in the British Empire record keeping methods were not mandated from the imperial centre. Instead, and in marked contrast to Belgian, Dutch, French and German practice, significant improvements in the design and implementation of record keeping systems were pioneered in the colonial periphery before being adopted in Whitehall. We have demonstrated, in addition, that this was not a simple linear process and have outlined the nature of the opposition to change and the techniques used to resist change in some of the colonies and in parts of Whitehall.

Hermeneutics is an approach that is not necessarily restricted to the past. The author has found that it is relevant in spatial as well as temporal terms. Working in African archives as a colleague rather than as a visiting researcher has enabled him to have some insight into the perspectives of African colleagues. Not least, it has brought home to him the consequences of a situation where the state is a virtual monopoly employer and the career-damaging consequences of offending political elites can be near catastrophic. ${ }^{.1}$

Fiduciarity is a concept borrowed by the emerging discipline of archives and records studies from the long-established profession of accountancy and its audit specialty in particular. ${ }^{\text {li }}$ In essence, fiduciarity is a stance that posits that arms-length systems need to be in place to enable and support good practice and, arguably, to protect those in the front office by separating them from direct responsibility for the design and implementation of systems in the back office. ${ }^{\text {lii }}$ High profile failings in the banking system have served to illustrate the value of financial systems which separate those 
who negotiate deals from those who authorise payments. There are clear parallels in relation to record keeping systems. The author has argued that the emergence of IT systems devised in the United States (where post-action filing ${ }^{\text {xliii }}$ has long been the norm) has put Commonwealth tradition of fiduciarity in record keeping systems (based on pre-action processing and filing) in jeopardy. ${ }^{\text {xliv }} \mathrm{He}$ has given particular attention to ways of over-coming this challenge. ${ }^{x / v}$

The author maintains that fiduciarity is best served where thinking about accountability is subjected to critical analysis. He sees the distinction between accountability as responsibility (making policy decisions and accepting responsibility if / when things go wrong) and accountability as probity (behaving ethically in the use of public or corporate resources) as vital. ${ }^{\text {xlvi }}$ This is precisely because archivists have long privileged the records of high-level decision-making bodies whilst neglecting the potential value of more mundane records. Experience in African countries, where corruption is an endemic challenge, has convinced him that strong record keeping systems have the potential to make a significant contribution to the restoration of ethical conduct, particularly if routine financial records are adequately catered for. However, unethical conduct is not the only challenge that arises in an African context. The author has identified two other crucial challenges to good record keeping: oral communication; and, the tendency to regard work as a place rather than an activity. The latter is of particular concern because it is linked to a widespread tendency to regard official IT systems as being available for recreational and personal use. .vii $^{\text {lvii }}$

Recent events in the West, not least the MPs expenses scandal in Britain, have demonstrated that ideas developed in African countries are relevant here too. ${ }^{\text {xliii }}$ In particular, the author has argued that the long-standing practices of record keeping professionals in their records appraisal activities need to be re-thought. Where, in the past, routine financial records were rapidly destroyed in their entirety, in the future they may need to be retained for much longer in support of probity. ${ }^{\text {xli }}$ Given the huge volume of such material, sampling techniques may need to be used.'

\section{Concluding remarks}

The author is inclined now to the view that post-modernist critiques have had a major impact for two distinct reasons. Firstly, because the ideas which they have supplanted were aligned with an old order and arguably with notions of Western hegemony in particular. Post-modernist critiques have provided fresh perspectives. A crucial aspect of these has been well expressed by Lemieux:

Impartiality and authenticity in records ... are essential to the effective production and operation of accountability, even as we recognize that these qualities are impossible to attain because of the mediated character of the record as a form of communication. As Verne Harris points out, at best the record serves only as one window on organizational and social processes. However, the record is, in the end, as Harris acknowledges, one of the best windows we have.

However, there is another and arguably darker side to the coin. Post-modernist approaches to archives and historical scholarship have had a particular appeal in recent decades because the expansion of higher education has out-stripped sources of funding for research in archives and research on archives. Meanwhile the emergence of an audit culture in the academy has placed tight time constraints on the publication of findings. Archival research can be time-consuming and expensive. The need to make research trips can also impose unwelcome delays on writing projects which increasingly are shaped to an agenda of 'publish or perish'. To be blunt, sitting in a room imagining the world outside is both cheaper and quicker than engaging with the difficult, messy and time-consuming business of carrying out original research in archives. The author believes that for post-modernist approaches to archive and records theory to have a beneficial effect it is profoundly 
helpful to supplement them with the concepts of hermeneutics and fiduciarity, which have been briefly outlined above.

The bulk of the author's work of the past forty years is in the tradition of literary scholarship. Published works, including academic writing, have been used alongside unpublished memoirs, personal papers and official archives. The use of archives to write about archives has proved productive of insights. One of the most significant of these has been evidence that the imperial imagination had less impact on the design of colonial record keeping systems than the functional

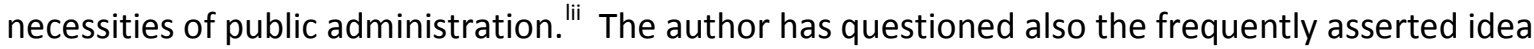
that the office was the locus of power in colonial administration, observing that much of the work of government was undertaken orally by peripatetic officials. liii These arguments have been sustainable precisely because a sufficient degree of detailed analysis has been achieved.

Some writers on record keeping have argued that much of professional practice and of the literature of the discipline is based on an outmoded concept of truth as absolute. Whilst the author agrees that positivistic notions of truth as uncomplicated and even self-evident are unsustainable, he has argued that it is not sufficient to demolish established verities and then walk away. If unrestrained moral relativism is allowed to replace positivist concepts then we run the risk of giving comfort and succour to those who are guilty of unethical conduct. Having worked in a number of developing countries, including Barbados, Ethiopia, Malawi, Rwanda, Tanzania and Zambia, the author is acutely aware of the dangers posed by a culture of impunity. liv

The tension between positivist concepts of truth and post-modernist explorations of alternatives provides a significant backdrop to debates about evidential value in current, largely digital, record keeping systems. In a workbook prepared for the public service in Malawi the author has referred to the work of Philip Bantin as an exemplar of the positivist tradition. ${ }^{\text {lv }}$ Bantin describes in detail a range of techniques and technical specifications by means of which to secure evidential value. ${ }^{\text {lvi }}$ Indeed, an article written by the author and Michael Moss represents an earlier (and much briefer) discussion of possible techniques for securing evidential value by technical means. ${ }^{\text {Ivi }}$ However, Bailey's work (published in the same year as Bantin's) demonstrates that unanticipated technical changes have tended to undermine attempts to produce comprehensive technical specifications. ${ }^{\text {Ivii }}$ The author's view is that in a rapidly changing world the key objective should be to secure a degree of evidential value that is satisfactory in the eyes of the courts and of regulatory bodies. Technical specifications may assist in this but they are not an end in themselves.

\section{Acknowledgements}

The author's thinking has developed as a result of many fruitful interactions with colleagues and students over a long period of time. He would like to give particular thanks to Dr Susan Stewart and $\mathrm{Dr}$ lan G Anderson who read and commented on earlier versions of this work. More broadly, the collegiate intellectual life of the Humanities Advanced Technology and Information Institute, most especially the weekly research seminar series, has proved beneficial. Within HATII particular acknowledgement is due to Dr James Currall, Dr James Girdwood, Professor Michael Moss, Professor Andrew Prescott and Professor Seamus Ross. Professor John McColl of the University of Glasgow's Department of Statistics and Dr Hamish Maxwell-Stewart now of the University of Tasmania are due credit for the development of the author's knowledge of statistical methods. Visiting research fellowships at Balliol College, Oxford, the University of Malawi and at Michigan and Stanford universities in the USA have provided a beneficial broadening of intellectual horizons. These would not have been possible without the support of the Fulbright Commission, Leverhulme Trust, Scotland-Malawi Partnership and Snell Foundation. The author should like to acknowledge the 
contribution of journal editors including Dr Jenny Bunn, Dr Sebastian Gurciullo, Professor Patrick Ngulube, Professor Julie McLeod and Dr Beth Yakel. Last but not least, the author would like to thank Richard A Storey formerly of the Modern Records Centre at Warwick University who helped to stimulate the author's thinking during a fruitful working partnership lasting more than a decade. 


\footnotetext{
${ }^{\mathrm{i}}$ The term orality denotes a society or culture in which there is a strong pre-disposition to conduct the business of life on the basis of verbal rather than written communication

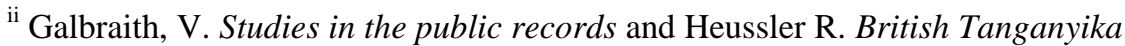

iii Tough, A.G. and Tough, Y. “Accountability and records appraisal”; Tough, A.G. Electronic Records Management in Malawi; Tough, A.G. "Accountability, open government and record keeping: time to think again?”; Tough, A.G. “Archives in sub-Saharan Africa half a century after independence.”; Tough, A.G. "Record keeping and accountability. Why the distinction between probity and responsibility matters."

${ }^{\text {iv }}$ Meredith, M. The state of Africa., p.687

v Tyacke, S. "Culture and politics of archives.”, p.20

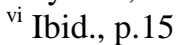

vii Ibid., p.18

viii Van Zyl, S. “Psychoanalysis and the archive: Derrida’s Archive fever.”, p.39

${ }^{i x}$ Derrida, J. Archive fever: a Freudian impression.

${ }^{x}$ Derrida, J. "Archive fever (A seminar by Jacques Derrida, University of the Witwatersrand, August 1998, transcribed by Verne Harris).”, p.38

${ }^{x i}$ Derrida, J. Archive fever: a Freudian impression. p.20

${ }^{x i i}$ Foucault, M. Madness and civilisation: a history of insanity in the age of reason.

xiii Byatt, A.S. Possession., p.302

${ }^{\mathrm{xiv}}$ Parry-Jones, W. The trade in lunacy: a study of private madhouses in England in the eighteenth and nineteenth centuries.

${ }^{\mathrm{xv}}$ Raffel, S. Matters of fact. A sociological enquiry.

${ }^{x v i}$ Maxwell-Stewart, H. and Tough, A.G. Selecting clinical records for long-term preservation.

${ }^{x v i i}$ Cameron, J.L., Laing, R.D. and McGhie, A. "Patient and nurse: effects of environmental change in the care of chronic schizophrenics.”; Laing, R.D. The facts of life.

xviii Abrahamson, D. R.D. "Laing and long-stay patients: discrepant accounts of the refractory ward and 'rumpus room’ at Gartnavel Royal Hospital.”

${ }^{\text {xix }}$ The case notes of this patient are now held in the NHS Greater Glasgow and Clyde Archives. They are awaiting cataloguing

${ }^{\mathrm{xx}}$ Blouin, F. “Archivists, mediation and constructs of social memory.” p.102. Blouin was instrumental in organising a series of seminars which resulted in the publication of Blouin, F. and Rosenburg, W. (eds)

Archives, documentation and institutions of social memory. Essays from the Sawyer Seminar.. This work in turn has been followed by Blouin, F. and Rosenburg, W. Processing the past. Contesting authority in history and archives. The author regards the earliest article as the seminal work.

${ }^{x x i}$ Blouin, F. “Archivists, mediation and constructs of social memory.” p.104

xxii Ibid. p.105. These arguments are further developed in Steedman, C. "“'Something she called a fever”:

Michelet, Derrida and Dust (Or, in the Archives with Michelet and Derrida)”

xxiii Ibid. p.106

${ }^{\text {xxiv }}$ Ibid. p.107. These arguments are further developed in Schwartz, J. “" Records of simple truth and

precision”: photography, archives and the illusion of control.” See also Harris, V. “A shaft of darkness: Derrida in the archive", pp.73-75

${ }^{x x v}$ Blouin, F. “Archivists, mediation and constructs of social memory.” p.108

${ }^{x x v i}$ Ibid. p.109

xxvii Ibid. p.108

xxviii Rosenburg, W. (2001) Politics in the (Russian) archives: the "objectivity question” trust and the limitations of law, American Archivist, 64(1 Rosenburg, W. "Politics in the (Russian) archives: the "objectivity question" trust and the limitations of law.”, p.81

xxix Stoler, L. "Colonial archives and the arts of governance: on the content in the form.”, p.86

xxx Gann, L. "Archives and the study of society."

xxxi Stoler, L. "Colonial archives and the arts of governance: on the content in the form.”, p.92

xxxii Derrida, J. "Archive fever (A seminar by Jacques Derrida, University of the Witwatersrand, August 1998, transcribed by Verne Harris).” p.48

xxxiii Lemieux, V. "Toward a "Third order" archival interface: research notes on some theoretical and practical implications of visual explorations in the Canadian context of financial electronic records” pp. 53-93

${ }_{\text {xxxiv }}$ Faulks, S. Human traces.

${ }^{x x x v}$ Gospel of St Matthew, chapter 13, verse 31

${ }^{\text {xxxvi }}$ Book of Leviticus, chapter 19, verse 19
} 
xxxvii I am grateful to Bob Johnstone for his exposition of these issues in a sermon preached at Mearns Kirk, near Glasgow, 18 Jan 2015

xxxviii The author should like to acknowledge the influence that James Girdwood's research seminar contributions have had on his thinking

xxxix Tough, A.G. and Lihoma, P. "Development of record keeping systems in the British Empire /

Commonwealth, 1870s - 1960s.”; Tough, A.G. "Oral culture, written records and understanding the twentiethcentury colonial archive: the significance of understanding from within; Tough, A.G. "Archives in sub-Saharan Africa half a century after independence."

${ }^{\mathrm{xl}}$ Tough, A.G. "Archives in sub-Saharan Africa half a century after independence."

xli Duranti, L. and Rogers, C. “Trust in records and data online.”, pp. 203-214

xlii The author should like to acknowledge the influence that Michael Moss's research seminar contributions have had on his thinking

xliii Post action filing is the practice of waiting until business transactions are completed before putting away the records generated. It stands in contrast to pre action workflow where records are processed and contextualised before being distributed for action to be taken

xliv Tough, A.G. "Records and the transition to the digital."

xlv Tough, A.G. Electronic Records Management in Malawi. An introductory workbook; Tough, A.G. "Records and the transition to the digital."; Moss, M. and Tough, A.G. "Metadata, controlled vocabulary and directories: electronic document management and standards for records management.”

xlvi Tough, A.G. "Record keeping and accountability. Why the distinction between probity and responsibility matters."

xlvii Tough, A.G. Electronic Records Management in Malawi. An introductory workbook

xlviii Tough, A.G. "Accountability, open government and record keeping: time to think again?"

xlix Tough, A.G. and Tough, Y. "Accountability and records appraisal."

${ }^{1}$ Maxwell-Stewart, H. and Tough, A.G. Selecting clinical records for long-term preservation.

${ }^{\mathrm{li}}$ Lemieux, V. "Let the ghosts speak: an empirical exploration of the "nature” of the record.”, p108

lii Tough, A.G. and Lihoma, P. "Development of record keeping systems in the British Empire / Commonwealth, 1870s - 1960s."

liii Tough, A.G. "Oral culture, written records and understanding the twentieth-century colonial archive: the significance of understanding from within."

liv Tough, A.G. and Tough, Y. "Accountability and records appraisal.”; Tough, A.G. Electronic Records

Management in Malawi. An introductory workbook; Tough, A.G. "Accountability, open government and record keeping: time to think again?"

${ }^{\mathrm{l}}$ Tough, A.G. Electronic Records Management in Malawi. An introductory workbook

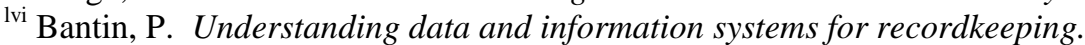

lvii Moss, M. and Tough, A.G. "Metadata, controlled vocabulary and directories: electronic document management and standards for records management."

lviii Bailey, S. Managing the crowd. Rethinking records management for the web 2.0 world.

\section{References}

Abrahamson, D. R.D. "Laing and long-stay patients: discrepant accounts of the refractory ward and 'rumpus room’ at Gartnavel Royal Hospital.” History of Psychiatry, 18, no. 2 (2007)

Bailey, S. Managing the crowd. Rethinking records management for the web 2.0 world. London: Facet Publishing, 2008

Bantin, P. Understanding data and information systems for recordkeeping. London: Facet, Publishing, 2008

Blouin, F. “Archivists, mediation and constructs of social memory.” Archival issues, 24, no. 2 (1999)

Blouin, F. and Rosenburg, W. (eds) Archives, documentation and institutions of social memory. Essays from the Sawyer Seminar. Ann Arbor: University of Michigan Press, 2006

Blouin, F. and Rosenburg, W. Processing the past. Contesting authority in history and archives. Oxford: OUP, 2011 
Book of Leviticus. In Holy Bible. New revised standard version, Cambridge: CUP, 2002

Byatt, A.S. Possession. London: Vintage, 1991

Cameron, J.L., Laing, R.D. and McGhie, A. "Patient and nurse: effects of environmental change in the care of chronic schizophrenics.” Lancet, 11 (1955)

Derrida, J. Archive fever: a Freudian impression. Translated by E. Prenowitz. Chicago and London: University of Chicago Press, 1996

Derrida, J. “Archive fever (A seminar by Jacques Derrida, University of the Witwatersrand, August 1998, transcribed by Verne Harris).” In Refiguring the archive, Edited by Hamilton, C. et al. Dordrecht: Kluwer Academic Publishers, 2002

Duranti, L. and Rogers, C. "Trust in records and data online.” In Integrity in government through Records Management. Essays in honour of Anne Thurston, Edited by Lowry, J. and Wamukoya, J. Dorset: Ashgate, 2014

Faulks, S. Human traces. London: Vintage 2006

Foucault, M. Madness and civilisation: a history of insanity in the age of reason. Translated by R. Howard. London: Tavistock, 1965

Galbraith, V. Studies in the public records. London: Thomas Nelson and Sons, 1948

Gann, L. “Archives and the study of society.” Rhodes-Livingstone Institute Journal, 20 (1956)

Gospel of St Matthew. In Holy Bible. New revised standard version, Cambridge: CUP, 2002

Harris, V. “A shaft of darkness: Derrida in the archive” In Refiguring the archive, Edited by Hamilton, C. et al. Dordrecht: Kluwer Academic Publishers, 2002

Heussler R. British Tanganyika. An essay and documents on district administration. Durham: Duke University Press, 1971

Laing, R.D. The facts of life. London: Allen Lane, 1976

Lemieux, V. "Let the ghosts speak: an empirical exploration of the "nature” of the record.” Archivaria, 51 (2001)

Lemieux, V. “Toward a “Third order” archival interface: research notes on some theoretical and practical implications of visual explorations in the Canadian context of financial electronic records” Archivaria, 78 (2014)

Maxwell-Stewart, H. and Tough, A.G. Selecting clinical records for long-term preservation. Glasgow: Wellcome Unit for History of Medicine, 1999

Meredith, M. The state of Africa. London: Free Press, 2005

Moss, M. and Tough, A.G. "Metadata, controlled vocabulary and directories: electronic document management and standards for records management.” Records Management Journal, 13, no. 1 (2003)

Parry-Jones, W. The trade in lunacy: a study of private madhouses in England in the eighteenth and nineteenth centuries. London: Routledge and Kegan Paul, 1971

Raffel, S. Matters of fact. A sociological enquiry. London: Routledge and Kegan Paul, 1979 
Rosenburg, W. "Politics in the (Russian) archives: the "objectivity question” trust and the limitations of law." American Archivist, 64, no. 1 (2001)

Schwartz, J. ““"Records of simple truth and precision”: photography, archives and the illusion of control.” In Blouin, F. and Rosenburg, W. (eds) Archives, documentation and institutions of social memory. Essays from the Sawyer Seminar. Ann Arbor: University of Michigan Press, 2006

Steedman, C. ““'Something she called a fever”: Michelet, Derrida and Dust (Or, in the Archives with Michelet and Derrida)” In Blouin, F. and Rosenburg, W. (eds) Archives, documentation and institutions of social memory. Essays from the Sawyer Seminar. Ann Arbor: University of Michigan Press, 2006

Stoler, L. "Colonial archives and the arts of governance: on the content in the form." In Refiguring the archive, Edited by Hamilton, C. et al. Dordrecht: Kluwer Academic Publishers, 2002

Tough, A.G. “Accountability, open government and record keeping: time to think again?” Records Management Journal, 21, no. 3 (2011)

Tough, A.G. “Archives in sub-Saharan Africa half a century after independence.” Archival Science, 9 (3-4) (2009)

Tough, A.G. Electronic Records Management in Malawi. An introductory workbook. Zomba: National Archives of Malawi, 2011

Tough, A.G. "Oral culture, written records and understanding the twentieth-century colonial archive: the significance of understanding from within.” Archival Science, 12, no. 3 (2011)

Tough, A.G. "Record keeping and accountability. Why the distinction between probity and responsibility matters.” Archives and Social Studies, 1, no. 1 (2007)

Tough, A.G. "Records and the transition to the digital.” In: Moss, M. and Tough, A.G. (eds) Record Keeping in a Hybrid Environment: Managing the Creation, Use, Preservation and Disposal of Unpublished Information Objects in Context. Oxford: Chandos, 2008

Tough, A.G. and Lihoma, P. "Development of record keeping systems in the British Empire / Commonwealth, 1870s - 1960s.” Archives \& Manuscripts, 40, no.3 (2012)

Tough, A.G. and Tough, Y. “Accountability and records appraisal.” ESARBICA Journal, 31 (2012)

Tyacke, S. “Culture and politics of archives.” Archivaria, 52 (2002)

Van Zyl, S. "Psychoanalysis and the archive: Derrida’s Archive fever.” In Refiguring the archive, Edited by Hamilton, C. et al. Dordrecht: Kluwer Academic Publishers, 2002 
References

Abrahamson, D. R.D. "Laing and long-stay patients: discrepant accounts of the refractory ward and 'rumpus room’ at Gartnavel Royal Hospital.” History of Psychiatry, 18, no. 2 (2007)

Bailey, S. Managing the crowd. Rethinking records management for the web 2.0 world. London: Facet Publishing, 2008

Bantin, P. Understanding data and information systems for recordkeeping. London: Facet, Publishing, 2008

Blouin, F. “Archivists, mediation and constructs of social memory.” Archival issues, 24, no. 2 (1999)

Blouin, F. and Rosenburg, W. (eds) Archives, documentation and institutions of social memory. Essays from the Sawyer Seminar. Ann Arbor: University of Michigan Press, 2006

Blouin, F. and Rosenburg, W. Processing the past. Contesting authority in history and archives. Oxford: OUP, 2011

Book of Leviticus. In Holy Bible. New revised standard version, Cambridge: CUP, 2002

Byatt, A.S. Possession. London: Vintage, 1991

Cameron, J.L., Laing, R.D. and McGhie, A. "Patient and nurse: effects of environmental change in the care of chronic schizophrenics.” Lancet, 11 (1955)

Derrida, J. Archive fever: a Freudian impression. Translated by E. Prenowitz. Chicago and London: University of Chicago Press, 1996

Derrida, J. “Archive fever (A seminar by Jacques Derrida, University of the Witwatersrand, August 1998, transcribed by Verne Harris).” In Refiguring the archive, Edited by Hamilton, C. et al. Dordrecht: Kluwer Academic Publishers, 2002

Duranti, L. and Rogers, C. "Trust in records and data online.” In Integrity in government through Records Management. Essays in honour of Anne Thurston, Edited by Lowry, J. and Wamukoya, J. Dorset: Ashgate, 2014

Faulks, S. Human traces. London: Vintage 2006

Foucault, M. Madness and civilisation: a history of insanity in the age of reason. Translated by R. Howard. London: Tavistock, 1965

Galbraith, V. Studies in the public records. London: Thomas Nelson and Sons, 1948

Gann, L. “Archives and the study of society.” Rhodes-Livingstone Institute Journal, 20 (1956)

Gospel of St Matthew. In Holy Bible. New revised standard version, Cambridge: CUP, 2002

Harris, V. “A shaft of darkness: Derrida in the archive” In Refiguring the archive, Edited by Hamilton, C. et al. Dordrecht: Kluwer Academic Publishers, 2002

Heussler R. British Tanganyika. An essay and documents on district administration. Durham: Duke University Press, 1971

Laing, R.D. The facts of life. London: Allen Lane, 1976

Lemieux, V. "Let the ghosts speak: an empirical exploration of the "nature” of the record.” Archivaria, 51 (2001) 
Lemieux, V. “Toward a "Third order” archival interface: research notes on some theoretical and practical implications of visual explorations in the Canadian context of financial electronic records” Archivaria, 78 (2014)

Maxwell-Stewart, H. and Tough, A.G. Selecting clinical records for long-term preservation. Glasgow: Wellcome Unit for History of Medicine, 1999

Meredith, M. The state of Africa. London: Free Press, 2005

Moss, M. and Tough, A.G. "Metadata, controlled vocabulary and directories: electronic document management and standards for records management.” Records Management Journal, 13, no. 1 (2003)

Parry-Jones, W. The trade in lunacy: a study of private madhouses in England in the eighteenth and nineteenth centuries. London: Routledge and Kegan Paul, 1971

Raffel, S. Matters of fact. A sociological enquiry. London: Routledge and Kegan Paul, 1979

Rosenburg, W. "Politics in the (Russian) archives: the "objectivity question" trust and the limitations of law." American Archivist, 64, no. 1 (2001)

Schwartz, J. ““'Records of simple truth and precision”: photography, archives and the illusion of control.” In Blouin, F. and Rosenburg, W. (eds) Archives, documentation and institutions of social memory. Essays from the Sawyer Seminar. Ann Arbor: University of Michigan Press, 2006

Steedman, C. ““'Something she called a fever”: Michelet, Derrida and Dust (Or, in the Archives with Michelet and Derrida)” In Blouin, F. and Rosenburg, W. (eds) Archives, documentation and institutions of social memory. Essays from the Sawyer Seminar. Ann Arbor: University of Michigan Press, 2006

Stoler, L. "Colonial archives and the arts of governance: on the content in the form.” In Refiguring the archive, Edited by Hamilton, C. et al. Dordrecht: Kluwer Academic Publishers, 2002

Tough, A.G. “Accountability, open government and record keeping: time to think again?” Records Management Journal, 21, no. 3 (2011)

Tough, A.G. “Archives in sub-Saharan Africa half a century after independence.” Archival Science, 9 (3-4) (2009)

Tough, A.G. Electronic Records Management in Malawi. An introductory workbook. Zomba: National Archives of Malawi, 2011

Tough, A.G. "Oral culture, written records and understanding the twentieth-century colonial archive: the significance of understanding from within.” Archival Science, 12, no. 3 (2011)

Tough, A.G. "Record keeping and accountability. Why the distinction between probity and responsibility matters.” Archives and Social Studies, 1, no. 1 (2007)

Tough, A.G. "Records and the transition to the digital.” In: Moss, M. and Tough, A.G. (eds) Record Keeping in a Hybrid Environment: Managing the Creation, Use, Preservation and Disposal of Unpublished Information Objects in Context. Oxford: Chandos, 2008

Tough, A.G. and Lihoma, P. "Development of record keeping systems in the British Empire / Commonwealth, 1870s - 1960s.” Archives \& Manuscripts, 40, no.3 (2012)

Tough, A.G. and Tough, Y. “Accountability and records appraisal.” ESARBICA Journal, 31 (2012)

Tyacke, S. “Culture and politics of archives.” Archivaria, 52 (2002) 
Van Zyl, S. "Psychoanalysis and the archive: Derrida’s Archive fever.” In Refiguring the archive, Edited by Hamilton, C. et al. Dordrecht: Kluwer Academic Publishers, 2002 